\title{
AN ANALYSIS OF THE STRATEGIES USED IN TRANSLATING IDIOMS IN INDONESIA INTO ENGLISH FOUND IN INDONESIAN LEGENDS
}

\author{
Donny Bhaskara Wicaksono, Erly Wahyuni \\ Universitas Muhammadiyah Malang
}

\begin{abstract}
In this global era, due to the growth of science, information, technology, and other people needs, translation becomes necessary in rendering information between languages. However, the process of translating is not as simple as switching the meaning of word for word based on the literal context.Idioms are one of the most problematical components of language. Idioms cannot be easily translated because of their unpredictable meaning and grammar. The purpose of this study is to find out; (1) the idiomatic expressions which are found in Indonesian Legends, (2) the meaning of the idiomatic expressions found in Indonesian Legends, and (3) the various strategies which are used in translating idioms in Indonesia into English found in Indonesian Legends.The descriptive qualitative research design, in the form of document analysis, was employed in this study. The instruments to collect the data were documents and expert opinion. Moreover, the documents consisted of the Bahasa Indonesia (Source Text) and English (Target Text) translation versions of five Indonesian Legends, namely; Batu Kuwung, Batu Menangis, Gunung Merapi, Tangkuban Perahu and Candi Prambanan. This study revealed that idiomatic expression translation strategy by paraphrasingwas the most dominant strategy used by the translator in translating the idiomatic expressions found in five Indonesian Legends (eleven out of eighteen cases). Meanwhile, the second most common strategy was translating by omission (six out of eighteen cases). The last was the strategy of using an idiom of similar meaning and form which only one out of eighteen cases. Thus, it can be concluded that the translator only applied three strategies out of the main five strategies of translating idiomatic expression suggested by Baker.
\end{abstract}

\section{Keywords: Idiomatic Expressions, Indonesian Legends, Translation Strategies.}

\section{INTRODUCTION}

English is an international language, spoken in many countries both as a native and as a second or foreign language. It is taught in the schools in almost every country on this earth. It is a living and vibrant language spoken by over 300 million people as their native language. Millions more people speak it as an additional language. Even though English has become an international language, a lot of problems appeared, for example, misunderstanding and misinterpreting. Moreover, there are still many countries using English as a foreign language, which means plenty of people around the world still do not understand English. As a result, translation is very indispensable process in converting information among different languages. Thus, it can make language available to people who do not understand English. 
In this global era, due to the growth of science, information, technology, and other people needs, translation becomes necessary in rendering information between languages. However, the process of translating is not as simple as switching the meaning of word for word based on the literal context. The result of a translation should serve the information in the target language without change the meaning in the source language. It involves grammatical understanding, linguistic comprehension, and a good sense of semantic analysis in order to get a proper translation. Moreover, there are some cases which often put translators into difficult situations, such as translators will find some words which actually do not represent its literal meaning which is known as idiom.

As translation becomes enormously important in global level, it is a subject values a closer study. Apparently, there is a wide range of topics that can be investigated in terms of translational aspects. This research happens to be one that focuses on strategy of idiom translations. Idioms are one of the most problematical components of language. Idioms cannot be abruptly translated because of their unpredictable meaning and grammar. Wang (2013) says that idiom is a language in the formation of the unique and fixed expressions in the using process. Furthermore, the special terms in idioms may be culture-bound and this potentially initiates the more complicated problem to the translator. Idioms may have both literal and figurative meaning. Several idioms can be translated literally, but then the meaning changes. Idiomatic meaning is more commonly used. In translating idioms, translator encounters various difficulties that cannot be simply overcome. The key problem is the lack of accuracy in the idiom level.

In line with the aforementioned background of the study, the researcher, furthermore, intends to reveal: 1) the idiomatic expressions found in Indonesian Legends; 2) the meaning of the idiomatic expressions found in Indonesian Legends and 3) the strategies used in translating idioms in Indonesia into English found in Indonesian Legends. 


\section{IDIOMS}

Makkai et al. (1995) argues that an idiom is the assigning of a new meaning to a group of words which already have their own meaning. An idiom is also defined as a group of words strung together to assume a specific meaning different from the meaning of each individual word (Lim, 2004). Furthermore, Baker (2000: 67) defines idiom as frozen patterns of language which allow little or no variation in form and often carry meanings which cannot be deduced from their individual components. It can have a literal meaning in one situation and a different idiomatic meaning in another situation.

Idiom can be found in every language. It is the other kind of figurative meanings contained in a language, such as in English (Simatupang, 2000: 49). There are so many idioms that sound difficult to understand especially by non-native speakers, such as old hand (a person who is experienced at a certain activity), lay down the marker (to set the standard), raining cats and dogs (hard raining), kick back (to relax) or make a splash (to do something that attracts attention). These expressions do not represent their literal meaning which makes them difficult to understand, as Lim (2004) states that idioms take different forms and are unclear in meaning on the surface structure.

From the explanations above, it can be said that idiom is an expression consists of a group of words which has a meaning that is not literally represented based on the words that make them up.

\section{THE DIFFICULTIES IN TRANSLATING IDIOMS}

In terms of difficulty, Baker (2011) claims that the main difficulty in translating goes to identifying the idiomatic expressions in which idiomatic expression is presumed easy to identify two different situations, they are: 1) when the idioms violate truth conditions and 2) when the idioms include expressions which seem grammatically ill-formed. Finally, she also 
concludes that when translators see sophisticated expressions that need deep understanding, they will detect such expressions as idioms.

However, some translators feel problematic in dealing with the idiomatic expressions. Therefore, Baker (2011) explains two major points related to the problems in translating idioms:

\section{Some idioms are misleading}

A number of idiomatic expressions are transparent-like due to their literal interpretations and meanings which are not representing the contextual meaning hidden. For exemplification, see the followings:

- Kick the bucket (die)

- Take someone for a ride (deceive or cheat someone in some way)

\section{The Source and Target Text's Idioms might be Closely Equivalent}

Idiomatic expressions sometimes look similar physically but have partial and complete difference in terms of meaning. To exemplify, notice the followings exemplification:

- To pull someone's leg means tell someone something untrue as a joke in order to shock them temporarily is identical on the surface to the idiom yushab rijlu [pull his leg] which is used in several Arabic dialects which means tricking someone into talking about something s/he would have rather kept secret.

\section{THE STRATEGIES IN TRANSLATING IDIOMS}

Referring to afore-discussed aspects, after facing some problems in translating idioms, translators automatically deal with the strategies that are going to be used. In this case, Baker (2011) shows the kinds of strategies in translating idioms by means of distinguishing the strategies of translating idiom into five kinds that will be explored in following paragraphs:

\section{Strategy 1 (Using an idiom with a similar meaning and form)}


Strategy 1 , by means of using an idiom with a similar meaning and form, accordingly implies the way of conveying roughly the similar meaning that automatically consists of equivalent lexical items. In this case, the similarity does not only rely in term of form, but also in their meaning. As the representative, see the following examples:

SL: We rarely dine out these weeks.

TL: Kita jarang makan diluar minggu ini.

From the example above, the idiomatic expression dine out is translated into makan diluar in the target language because the SL and TL has idiomatic meaning and form. In addition, the context is included into literal expression in the SL and TL, because based on the form, it has similar literal element. It will be in the same constructions in meaning when it is translated back into English because of its similar meaning and form in both languages.

\section{Strategy 2 (Using an idiom of a similar meaning but dissimilar form)}

This strategy is originally suggested by Baker as in first strategy with similar meaning, but in this case, lexical items are not utilized.

Example:

SL: Don't keep on, I will back it out in a minute.

TL: Jangan teruskan, aku akan kembali beberapa menit.

From the example above, the Strategy 2 is generated to translate keep on into teruskan. Based on the context, keep on has similar meaning with go on. In this case, keep on which means teruskan has an idiomatic meaning because it is dissimilar in literal meaning. It also has dissimilar meaning when it is translated back into English because of its similar meaning and dissimilar form in both languages.

\section{Strategy 3 (Translating by paraphrase)}


This strategy is the most common way used in translating idioms when a match cannot be found in the target language or when it seems inappropriate to use idiomatic language in the target text because of differences in stylistics preferences of the source and target languages. This strategy is not accurate but acceptable.

Example:

SL: Sky really pissing down here at the moment.

TL: Langit sungguh hujan lebat saat ini.

In order to make the meaning sounds more natural in the Target Language, so pissing down is translated into hujan lebat. From the explanation above, it can be deduced that the researcher is unable to find appropriate idiomatic expression in the Target Language to translate the idiom piss down. It proves that the idiomatic expression is translated by paraphrasing because of differences in style of the source and the target languages.

\section{Strategy 4 (Translation by omission)}

Omission is used when Idiom has no close match in TL, its meaning cannot be easily paraphrased, or for stylistic reasons. According to Baker (2011) omission is allowed only in some following cases:

1. First, when there is no close comparable in the target language;

2. Secondly, when it is not easy to paraphrase;

3. Finally, an idiom may be omitted for stylistic reasons. This strategy is not used very frequently.

To exemplify, moreover, see the following example:

SL: ... not talk about their religion affiliation at all.

TL: ... tak ingin membicarakan mengenai afiliasi agama mereka. 
From the example above, the phrase at all is omitted because it would be of any use. It had better to omit one of these idiomatic expressions, so that it would sound more natural in the TL.

\section{Strategy 5 (Compensation)}

This strategy has two steps: omit the idiom, then replace and insert the other idiom in another position. This strategy is used if translator cannot use another strategy to translate idiom, then he/she omits the idiom, replaces and inserts it in another place.

\section{METHOD}

In accordance with this research, there were some objects that were categorized as legends. In addition, Indonesian legends were more preferred to select by the researcher. Five legends were chosen as the objects of this research, namely Tangkuban Perahu, Gunung Merapi, Batu Menangis, Candi Prambanan, and Batu Kuwung. Furthermore, the scripts were in the two versions, English and Indonesian, which were taken from www.ceritarakyatnusantara.com.

\section{FINDINGS}

\section{Strategies Used by the Translator for Translating the Idiomatic Expressions Found in Indonesian Legends}

In accordance with the data that had been already investigated by the researcher, there were three strategies of translating the idiomatic expressions used by the translator in translating Indonesian legends; they were: similar meaning and similar form, paraphrasing and omission. Each strategy would be comprehensively showed in the following points.

\section{Translation by Similar Meaning and Similar Form}

Revisiting the definition of similar meaning and similar form strategy used for translating the idiomatic expressions, the main point of this strategy was that the ST's idiomatic expressions were to be translated into the same construction of idiomatic 
expressions as well in TT. Moreover, this research revealed that there was only one idiomatic expression translated by using this strategy.

\section{Translation by Paraphrasing}

Paraphrasing was used in translating idioms when a match cannot be found in the target language or when it seemed inappropriate to use idiomatic language in the target text because of differences in stylistics preferences of the source and target language.

After doing the analysis on the idiomatic expressions, the researcher found out 11 out of 18 cases of translation by paraphrasing found in Indonesian legends.

\section{Translation by Omission}

Omission was used when Idiom has no close match in TL, its meaning cannot be easily paraphrased, or for stylistic reasons. Afterwards, after the data were analyzed, the researcher found six idiomatic expressions translated by means of omission technique. In the whole legends, the researcher found there are 6 out 18 cases. For the completed data, see the table below.

Table 1. Strategies Used by the Translator for Translating the Idiomatic Expressions Found in Indonesian Legends

\begin{tabular}{|c|c|c|c|}
\hline \multirow[b]{2}{*}{ No. } & ST & TT & \multirow{2}{*}{ Strategy } \\
\hline & Sentc. & Sentc. & \\
\hline 1 & $\begin{array}{l}\text { Akhirnya, keduanya pun saling } \\
\text { jatuh cinta. }\end{array}$ & $\begin{array}{l}\text { They soon fell in love with each } \\
\text { other. }\end{array}$ & $\begin{array}{l}\text { Similar Meaning and } \\
\text { similar form }\end{array}$ \\
\hline 2 & $\begin{array}{l}\text { Lambat laun cerita dari mulut } \\
\text { ke mulut itu pun tersebar } \\
\text { hingga ke penjuru desa. }\end{array}$ & $\begin{array}{l}\text { Slowly, the story spread } \\
\text { throughout the kingdom. }\end{array}$ & Paraphrasing \\
\hline 3 & $\begin{array}{l}\text { Laksana disambar petir orang } \\
\text { tua itu mendengar ucapan } \\
\text { putrinya. }\end{array}$ & $\begin{array}{l}\text { Darmi`s mother was totally } \\
\text { shocked to hear that. }\end{array}$ & Paraphrasing \\
\hline 4 & $\begin{array}{l}\text { Dasar memang keras kepala } \\
\text { kedua empu itu. }\end{array}$ & How obstinate!! & Paraphrasing \\
\hline 5 & Mereka harus diberi pelajaran. & $\begin{array}{l}\text { We have to teach them a } \\
\text { lesson! }\end{array}$ & Paraphrasing \\
\hline 6 & $\begin{array}{l}\text { Prabu Baka pun tidak tinggal } \\
\text { diam. }\end{array}$ & King Baka reacted instantly. & Paraphrasing \\
\hline 7 & $\begin{array}{l}\text { Bandung Bondowoso } \\
\text { mengundang balatentaranya } \\
\text { yang berupa makhluk halus } \\
\text { tersebut. }\end{array}$ & $\begin{array}{l}\text { he called on his unseen troop of } \\
\text { spirits to help him out. }\end{array}$ & Paraphrasing \\
\hline
\end{tabular}




\begin{tabular}{|c|c|c|c|}
\hline 8 & $\begin{array}{l}\text { Roro Jonggrang kembali } \\
\text { berpikir keras dan ia pun } \\
\text { menemukan jalan keluarnya. }\end{array}$ & $\begin{array}{l}\text { Rara Jonggrang went on } \\
\text { thinking strenuously and finally } \\
\text { found an idea. }\end{array}$ & Paraphrasing \\
\hline 9 & $\begin{array}{l}\text { Prabu Sungging membuang air } \\
\text { kecil pada daun caring. }\end{array}$ & $\begin{array}{l}\text { Prabu Sungging urinated on } \\
\text { taro leaves. }\end{array}$ & Paraphrasing \\
\hline 10 & $\begin{array}{l}\text { Tiba-tiba seekor babi yang } \\
\text { bernama Wayungyang datang } \\
\text { meminum air seninya. }\end{array}$ & $\begin{array}{l}\text { A female boar called } \\
\text { Wayungyang came and drank } \\
\text { his widdle. }\end{array}$ & Paraphrasing \\
\hline 11 & $\begin{array}{l}\text { Ia tidak ingin terjadi } \\
\text { pertumpahan darah di antara } \\
\text { para raja dan pangeran tersebut } \\
\text { dengan hanya menerima salah } \\
\text { satu pinangan dari mereka. }\end{array}$ & $\begin{array}{l}\text { She was afraid that her } \\
\text { accepting one of the proposals } \\
\text { would cause wars among the } \\
\text { men. }\end{array}$ & Paraphrasing \\
\hline 12 & Dasar anak tidaktahu diri! & You wretched, ungrateful son! & Paraphrasing \\
\hline 13 & $\begin{array}{l}\text { Setiap sore ia selalu hilir- } \\
\text { mudik di kampungnya tanpa } \\
\text { tujuan yang jelas, kecuali hanya } \\
\text { untuk mempertontonkan } \\
\text { kecantikannya. }\end{array}$ & $\begin{array}{l}\text { One of her bad habits was } \\
\text { showing off her beauty to the } \\
\text { local people living in the } \\
\text { surroundings. }\end{array}$ & Omission \\
\hline 14 & $\begin{array}{l}\text { Oleh karena kedua belah pihak } \\
\text { tetap teguh pada pendirian } \\
\text { masing-masing, akhirnya } \\
\text { terjadilah perselisihan di antara } \\
\text { mereka. }\end{array}$ & $\begin{array}{l}\text { Seeing no solution, they } \\
\text { inevitably came to blows. }\end{array}$ & Omission \\
\hline 15 & $\begin{array}{l}\text { Tak ayal, pertarungan sengit } \\
\text { pun tak terhindarkan. }\end{array}$ & Both sides clashed fiercely. & Omission \\
\hline 16 & $\begin{array}{l}\text { Bandung Bondowoso } \\
\text { menyatakan maksud hatinya } \\
\text { kepada Raja Jonggrang. }\end{array}$ & - & Omission \\
\hline 17 & $\begin{array}{l}\text { Tanpa berpikir panjang, ia pun } \\
\text { membawa pulang bayi itu ke } \\
\text { istana. }\end{array}$ & $\begin{array}{l}\text { He took the poor baby back to } \\
\text { town. }\end{array}$ & Omission \\
\hline 18 & $\begin{array}{l}\text { Setelah berpikir keras, } \\
\text { akhirnya ia pun menemukan } \\
\text { sebuah cara. }\end{array}$ & $\begin{array}{l}\text { An idea finally came across her } \\
\text { mind. }\end{array}$ & Omission \\
\hline
\end{tabular}

\section{DISCUSSION}

After analysing the data related to idiomatic expressions found in the Indonesian legends, the researcher here was about to bring up some concepts related to the findings to discuss. The researcher found out eighteen (18) idiomatic expressions in total of which literal meanings were completely different from the idiomatic ones. This was because that idiomatic expressions often used figurative meanings in which it required the translator to be able to find out the appropriately equal meanings of which. 
To be able to arrive at the goal for finding out the equal meanings of idiomatic expressions, it was of urgency for the translator to prepare for the technique to translate those expressions. Based on the theory proposed by Baker, (2011), there are five strategies used in translating idiomatic expressions. However, this study revealed that the translator only used three techniques to translate all eighteen idiomatic expressions; they were paraphrasing, similar meaning similar form, and omission.

Furthermore, in this study, the researcher found that paraphrasing was the most-used strategy employed by the translator. It was reflected from the number of idiomatic expressions translated by means of paraphrasing, which were eleven items out of eighteen items in total. This finding was in line with Wati (2014) who also found paraphrasing as the most used technique in translating idiomatic expressions. In the previous research, she investigated the strategies of translating idioms in recount text from English into Indonesian used by English Department Students of University of Muhammadiyah Malang. She found that out of the other five strategies, the most common strategy in translating idiom was translating by paraphrasing. It was further investigated that the choice of translating by paraphrasing was mostly chosen because it was flexible than any other strategies and might be that the translators could not find the appropriate idiomatic language in the target language. In addition, it was also in line with Baker's notion which says that translation by paraphrasing is the most common way of translating idioms (2011).

The second most-used strategy in translating the idiomatic expressions was omission, which were six out of eighteen items. In this case, based on the data analysis, some of the idiomatic expressions were omitted due to the stylistic reason. It was match with Baker's theory which says that the idiomatic expressions will be paraphrased if there is no close match in the target language, its meaning cannot be easily paraphrased, or for stylistic reasons (Baker, 2011: 85). 


\section{CONCLUSION}

Based on the research findings in the previous chapter, some conclusions can finally be drawn. Several idiomatic expressions are found in five Indonesian Legends, namelyTangkuban Perahu, Malin Kundang, Gunung Bromo, Candi Prambanan, and Danau Toba. There are eighteen idiomatic expressions found in source texts of Indonesian Legends which are idiomatic expressions in Bahasa Indonesia.

Furthermore, there are strategies of translating idiom which have been suggested by Baker applied in the process of translation of idiomatic expressions from Bahasa Indonesia into English. However, thereare only three out of five strategies only found in translating five Indonesian Legends from Bahasa Indonesia into English. Meanwhile, the translation by paraphrasing was the most strategy applied (eleven out of eighteen cases). Then the translation by omission strategy was the next frequent strategy (six out of eighteen cases). In addition, the translation by similar meaning and similar form strategy was infrequent to use (only one case out of eighteen cases).

\section{REFERENCES}

Baker, M. (2011). In other words: A course book on translation. Abingdon: Routledge.

Lim, T.C. (2004). Advanced English idioms for effective communication. Jakarta: Penerbit Erlangga.

Makkai, B., and Gates. (1995). A dictionary of American idioms. New York: Barron's Educational Series, Inc.

Simatupang, M.D.S. (2000). Pengantar Teori Terjemahan. Universitas Indonesia: Jakarta

Wang, L. \& Wang, S. (2013).A study of idiom translation strategies between English and Chinese. Theory and practice in language studies, Vol. 3, No. 9, pp. 1691-1697, September 2013. Retrieved from http://www.academypublication.com/issues/past/tpls/vol03/09/27.pdf

Wati, C.D. (2014). The strategies of translating idioms in recount text from English into Indonesian used by English Department students of University of Muhammadiyah Malang. Unpublished Thesis. Malang: The Undergraduate Programme of University of Muhammadiyah Malang. 